\title{
IL-15 is an inflammatory mediator in the tumor microenvironment
}

\author{
Scott M Anthony ${ }^{1}$, Gabriel Pham², Kimberly S Schluns ${ }^{3 *}$ \\ From 30th Annual Meeting and Associated Programs of the Society for Immunotherapy of Cancer (SITC 2015) \\ National Harbor, MD, USA. 4-8 November 2015
}

Previous studies have shown that activation of the Stimulator of Interferon Genes (STING) pathway is important for regulating type I Interferons (IFN) in tumors. Furthermore, tumor DNA induces IL-15 and IL15R $\alpha$ mRNA in cultured dendritic cells (DC) in a STINGdependent manner. Since we have recently shown type I IFNs induce soluble IL-15R $\alpha /$ IL-15 complexes (sIL-15 complexes), we set out to determine if sIL-15 complexes are produced in tumor microenvironment and are regulated by STING signaling. To determine if STING induces sIL-15 complexes, mice were given STING agonists (c-diGMP) either i.v. or i.p. One day later, sIL-15 complexes were increased in serum and splenic homogenates of STING-treated mice. In addition, STING agonists directly induced sIL-15 complexes in BM-derived DCs. To examine sIL-15 complexes in the tumor microenvironment, B16-F10 tumors of various sizes were isolated from mice and sIL-15 complexes were measured in homogenates from tumors, draining lymph nodes, and spleen. Interestingly, levels of sIL-15 complexes were high in homogenates from small tumors (less than $100 \mathrm{~mm}^{2}$ ) and their draining lymph nodes but low in larger tumors. These findings suggest IL-15 is an inflammatory factor produced during early tumor development. To investigate the role of IL-15 within the tumor microenvironment, we analyzed tumor growth in mice conditionally deleted of IL-15R $\alpha$ (IL-15R $\alpha$ floxed X ER-Cre Tg). Unlike IL-15R $\alpha$-/- mice, this model system allows examination of lymphocytes that have developed in the presence of IL-15 signals. In mice conditionally deleted of IL-15R $\alpha$ (Tamoxifen-treated IL$15 R \alpha$ floxed X ER-Cre Tg mice), tumor growth was increased compared to control mice (Tamoxifen treated IL-15R $\alpha$ floxed mice). Overall, these studies suggest that IL-15 is a component of the inflammatory milieu of the

\footnotetext{
${ }^{3}$ The University of Texas MD Anderson Cancer Center/Department of Immunology, Houston, TX, USA

Full list of author information is available at the end of the article
}

tumor microenvironment that likely contributes to native anti-tumor responses. This work was supported by a seed fund from the Center for Inflammation and Cancer at the MD Anderson Cancer Center and a Cancer Prevention and Research Institute of Texas Research Training Award.

\section{Authors' details}

'University of Texas MD Anderson Cancer Center/Department of Immunology/The University of Texas Graduate School of Biomedical Sciences at Houston, Houston, TX, USA. ${ }^{2}$ University of Cincinnati College of Medicine, Cincinnati, OH, USA. ${ }^{3}$ The University of Texas MD Anderson Cancer Center/Department of Immunology, Houston, TX, USA.

Published: 4 November 2015

doi:10.1186/2051-1426-3-S2-P417

Cite this article as: Anthony et al.: IL-15 is an inflammatory mediator in the tumor microenvironment. Journal for ImmunoTherapy of Cancer 2015 3(Suppl 2):P417.

\section{Submit your next manuscript to BioMed Central and take full advantage of: \\ - Convenient online submission \\ - Thorough peer review \\ - No space constraints or color figure charges \\ - Immediate publication on acceptance \\ - Inclusion in PubMed, CAS, Scopus and Google Scholar \\ - Research which is freely available for redistribution \\ Submit your manuscript at www.biomedcentral.com/submit}

